dr n. med. Sławomir Pilip ${ }^{1}$

mgr Anita Wójcik ${ }^{1}$

dr n. med. Grzegorz Michalak ${ }^{1}$

dr n. med. Robert Gałązkowski ${ }^{1}$

Przyjęty/Accepted/Принята: 02.10.2014;

Zrecenzowany/Reviewed/Рецензирована: 19.05.2015;

Opublikowany/Published/Опубликована: 30.06.2015;

\title{
Wiedza w zakresie resuscytacji krążeniowo-oddechowej u osób zatrudnionych w wybranych jednostkach współpracujących z systemem państwowego ratownictwa medycznego ${ }^{2}$
}

\author{
Knowledge of Cardiopulmonary Resuscitation Among People Employed in Selected \\ Units Cooperating with the National Emergency Medical Services
}

\author{
Знания в области сердечно-лёгочной реанимации персонала, работающего \\ в выбранных подразделениях, сотрудничающих с системой государственной \\ неотложной медицинской помощи
}

\begin{abstract}
ABSTRAKT
Cel: Oceniano poziom wiedzy strażaków Państwowej (PSP) i Ochotniczej Straży Pożarnej (OSP), policjantów oraz ratowników Wodnego Ochotniczego Pogotowia Ratunkowego (WOPR) w zakresie prowadzenia resuscytacji krążeniowo-oddechowej.

Projekt i metody: Rozdano łącznie 165 kwestionariuszy ankiety zawierającej pytania ogólne dotyczące miejsca i stażu pracy, płci, wieku, wykształcenia ankietowanych i odbytych szkoleń oraz 17 pytań na temat resuscytacji krążeniowo-oddechowej. Pytania dotyczyły przede wszystkim rozpoznania nagłego zatrzymania krążenia oraz znajomości procedur BLS, m.in. sposobu udrożnienia dróg oddechowych, techniki uciskania klatki piersiowej, zastosowania automatycznego defibrylatora zewnętrznego oraz sposobu postępowania z pacjentem nieprzytomnym.

Wyniki: Dla ratowników WOPR, strażaków PSP i OSP oraz policjantów odsetek prawidłowych odpowiedzi wynosił odpowiednio 79\%, 59\%, 46\% i 52\%. Największy odsetek prawidłowych odpowiedzi obserwowano w grupie wiekowej 18-30 lat - 72\% oraz pośród respondentów ze stażem pracy poniżej 5 lat - 76\%. Nagłe zatrzymanie krążenia prawidłowo potrafiło rozpoznać (odpowiedź w ankiecie - pacjent nieprzytomny, bez oznak krążenia) ponad 80\% ratowników WOPR i strażaków PSP oraz 57\% strażaków OSP i 53\% policjantów. Odsetek prawidłowych odpowiedzi na pytania dotyczące sposobu udrożnienia dróg oddechowych (odpowiedź - odchylenie głowy do tyłu i uniesienie żuchwy), miejsca ułożenia rąk na klatce piersiowej podczas BLS osoby dorosłej (odpowiedź - środek klatki piersiowej), wymaganej częstości uciśnięć (odpowiedź 100-120/minutę) oraz stosunku uciśnięć do wentylacji (odpowiedź - 30:2) wynosił odpowiednio dla WOPR - 80\%, 74\%, 80\% i 86\%, PSP - 92\%, 50\%, 55\% i 70\%, OSP - 57\%, 27\%, 33\% i 65\%, policji - 71\%, 20\%, 17\% i 60\%. Większość badanych (WOPR - 89\%, OSP - 73\%, PSP - 68\%, policja - 57\%) twierdzi prawidłowo, że automatyczna zewnętrzna defibrylacja polega na zastosowaniu impulsu elektrycznego w celu przywrócenia prawidłowej pracy serca. W przypadku pacjenta nieprzytomnego z zachowanym oddechem prawidłowe postępowanie (odpowiedź - ułożenie w pozycji bezpiecznej) zastosowaliby wszyscy ratownicy WOPR, $65 \%$ strażaków OSP, $60 \%$ policjantów oraz $35 \%$ strażaków PSP.

Wnioski: Poziom wiedzy badanych należy ocenić jako niewystarczający, a system szkoleń, w których uczestniczyli, jako mało efektywny w zakresie wiedzy teoretycznej dotyczącej problematyki resuscytacji krążeniowo-oddechowej.
\end{abstract}

Słowa kluczowe: resuscytacja, ratownictwo

Typ artykułu: oryginalny artykuł naukowy

Warszawski Uniwersytet Medyczny / Medical University of Warsaw, Poland; slawomir.pilip@wum.edu.pl;

2 Autorzy wnieśli równy wkład merytoryczny w powstanie artykułu / The authors contributed equally to this article; 


\section{A BSTRACT}

Aim: This paper evaluates the level of knowledge for national and voluntary firefighters, police officers as well as members of the Voluntary Water Rescue Service (VWRS), in the application of cardiopulmonary resuscitation.

Project and methods: Research was conducted with the use of questionnaires. Some 165 questionnaires were distributed, containing general questions about the place of work, work experience, gender, age, education and training as well as 17 content-related questions about knowledge of cardiopulmonary resuscitation. Questions were concerned, above all, with the proper diagnosis of a sudden cardiac arrest, knowledge of the chest compression technique, usage of a defibrillator and the method of treating unconscious people.

Results: Correct responses were provided by: $79 \%$ of members from the VWRS, $59 \%$ national firefighters, $46 \%$ voluntary firefighters and $52 \%$ police officers. The largest percentage of correct responses was observed in the $18-30$ age group at $72 \%$ and from respondents with short period work experience (less than 5 years) at $76 \%$. A proper diagnosis of a sudden cardiac arrest (Answer: unconscious and without life functions) was provided correctly by over $80 \%$ of members from the VWRS and national firefighters, $57 \%$ voluntary firefighters and $53 \%$ police officers. The percentage of correct responses to questions concerned with unblocking an airway passage (Answer: tilt the head backwards and lift the jaw), the location of hands on an adult's chest when applying the chest compression technique (Answer: the middle of a chest), required frequency of chest compression (Answer: 100-120 per minute) and proportion of compressions to defibrillations (Answer: 30:2) was provided at a level of; 80\%, 74\%, 80\% and 86\% for VWRS, 92\%, 50\% and 55\% for national fire fighters, 57\%, 27\%, $33 \%$ and $65 \%$ for volunteer firefighters, $71 \%, 20 \%, 17 \%$ and $60 \%$ for the police. The majority of those questioned (VWRS $89 \%$, volunteer firefighters $73 \%$, national firefighters $68 \%$ and police $57 \%$ ) correctly stated that the purpose of a defibrillator is to apply an electric impulse with the aim of restoring the correct function of the heart. In circumstances where the patient is unconscious, but breathing, the correct approach (Answer: place the patient in the recovery position) was identified by all members of VWRS, $65 \%$ of volunteer firefighters, $60 \%$ of police officers and $35 \%$ of national firefighters.

Conclusions: From the research sample it is assessed that the level of knowledge is inadequate and the training system, which the respondents took part in as ineffective, from the view point of theoretical knowledge concerning cardiopulmonary resuscitation.

Keywords: resuscitation, emergency rescue

Type of article: original scientific article

\section{АННОТАЦИЯ}

Цель: Был оценен уровень знаний принципов сердечно-лёгочной реанимации у пожарных Государственной (PSP) и Добровольной Пожарных Служб (OSP), полицейских и спасателей Добровольной Службы Спасения На Boде (WOPR).

Проект и методы: Было роздано в общем 165 анкет, содержащих общие вопросы про место и стаж работы, пол, возраст, образование и курсы, которые прошли участники опроса, а также 17 вопросов, связанных с сердечно-лёгочной реанимацией. Вопросы касались, прежде всего, распознания внезапной остановки кровообращения и знания процедур BLS (Basic Life Support - алгоритмов базовой поддержки жизни), в том числе, способа очистки дыхательных путей, компрессии грудной клетки, использования внешнего автоматического дефибриллятора и способа оказания помощи больному без сознания.

Результаты: Для спасателей Добровольной Службы Спасения На Воде (WOPR), пожарных Государственной и Добровольной Пожарных Служб (PSP, OSP), а также полицейских процент правильных ответов на все вопросы составил соответственно $79 \%, 59 \%, 46 \%, 52 \%$. Наибольший процент правильных ответов был замечен среди возрастной группы $18-30$ лет - 72\% и среди респондентов со стажем ниже 5 лет - 76\%. Как правильно распознать внезапную остановку сердца (ответ в анкете - пациент без сознания, без симптомов кровообращения) знали свыше $80 \%$ спасателей WOPR и пожарных PSP, а также 57\% пожарных из OSP и 53\% полицейских. Процент правильных ответов на вопросы, касающиеся способа очистки дыхательных путей (ответ - отклонение головы назад и поднятие нижней челюсти), места положения рук на грудной клетке во время BLS взрослого человека (ответ - центр грудной клетки), необходимой частоты компрессии (ответ 100-120 в минуту) и соотношения компрессии к вентиляции (ответ 30:2) составил соответственно для WOPR 80\%, 74\%, 80\% і 86\%, PSP 92\%, 50\%, 55\% и 70\%, OSP 57\%, 27\%, 33\% і 65\%, полиции 71\%, 20\%, 17\% і 60\%. Большинство анкетированных (WOPR - 89\%, OSP - 73\%, PSP - 68\%, Полиция - 57\%) правильно ответила, что внешняя автоматическая дефибрилляция заключается в использовании электрического импульса с целью восстановления правильной работы сердца. В случае пациента, находящегося без сознания, с сохранённым дыханием, правильно бы себя повели (ответ - расположение пациента в безопасной позиции) все спасатели из WOPR, 65\% пожарных из OSP, 60\% полицейских и 35\% пожарных из PSP.

Выводы: Уровень знаний респондентов следует оценить как недостаточный, а систему обучения, в которой участвовали мало эффективной в сфере теоретических знаний относительно проблематики сердечно-лёгочной реанимации.

Ключевые слова: сердечно-лёгочная реанимация, спасение

Вид статьи: оригинальная научная работа

\section{Wprowadzenie}

Kardiolodzy w sformułowaniach „czas to mięsień” albo „czas to serce” - podkreślają konieczność jak najszybszego rozpoznania i leczenia pacjentów z ostrym zespołem wieńcowym. Neurolodzy stwierdzeniem, że „czas to mózg”, przypominają o tym, że wczesne rozpoznanie ostrego incydentu mózgowego daje szersze spektrum możliwości terapeutycznych, a zwłaszcza możliwość wdrożenia leczenia trombolitycznego u chorych ze świeżym udarem niedokrwiennym mózgu [1]. Lekarze medycyny ratunkowej, ratownicy medyczni, pielęgniarki systemu mają tylko 4 minuty od momentu zatrzymania krążenia na to, aby resuscytacja krążeniowo-oddechowa miała szansę stać się skuteczną reanimacją. Zatem w stanie nagłego zagrożenia zdrowotnego czas rozpoznania i udzielenia skutecznej pomocy odgrywa podstawową rolę. 
Dotarcie w ciągu 3-4 minut do pacjenta $\mathrm{z}$ objawami zatrzymania krążenia przez wykwalifikowany personel posiadający kompetencje do udzielania zaawansowanych zabiegów ratujących życie (ALS) to zadanie trudne albo wręcz niemożliwe, zwłaszcza w warunkach pozaszpitalnych. Dlatego system Państwowego Ratownictwa Medycznego współpracuje $\mathrm{z}$ innymi jednostkami, których zadaniem jest między innymi udzielanie skutecznego wsparcia w zakresie kwalifikowanej pierwszej pomocy (KPP) lub podstawowych zabiegów ratujących życie (BLS). Z systemem PRM współpracują między innymi jednostki ochrony przeciwpożarowej włączone do krajowego systemu ratowniczo-gaśniczego: Państwowa Straż Pożarna (PSP) i Ochotnicza Straż Pożarna (OSP), poza tym także policja oraz Wodne Ochotnicze Pogotowie Ratunkowe (WOPR). Uruchomienie łańcucha przeżycia przez świadków zdarzenia, w tym w razie konieczności zaangażowanie jednostek udzielających KPP i w końcu prawidłowo wdrożony ALS stanowią nierozerwalną całość warunkującą powodzenie reanimacji. Wdrożenie BLS zapewnia niewielki, ale wystarczający dla mózgu i serca przepływ krwi, tym samym zwiększa prawdopodobieństwo skutecznej defibrylacji i powrotu rytmu serca [2]. Osoby, u których podjęto natychmiastowe czynności resuscytacyjne, mają szansę powrotu do zdrowia i samodzielnego funkcjonowania w codziennym życiu.

W świetle powyższych faktów oczywiste wydaje się, że umiejętności osób wykonujących RKO nie powinny budzić żadnych wątpliwości, zwłaszcza jeżeli świadczone są w ramach profesjonalnych jednostek współpracujących z systemem PRM. W pracy podjęto próbę oceny znajomości zasad prowadzenia resuscytacji krążeniowo-oddechowej przez strażaków PSP i OSP, policjantów oraz ratowników WOPR.

\section{Metody}

Badanie przeprowadzono w oparciu o technikę ankietowania w okresie od kwietnia do maja 2012 roku. Kwestionariusz ankiety wypełniła anonimowo losowo wybrana grupa respondentów pracujących w poszczególnych jednostkach współpracujących z systemem PRM. Ankietowani zostali poinformowani o celu badania. Respondenci wypełniali kwestionariusze ankiety samodzielnie, w obecności osoby sprawującej nadzór nad badaniem, na terenie zakładu pracy.

Rozdano łącznie 165 kwestionariuszy ankiety, w tym: 35 w WOPR, $40 \mathrm{w}$ jednostce policji, $50 \mathrm{w}$ OSP i $40 \mathrm{w}$ PSP. Po dokonaniu przeglądu ankiet i wstępnej analizie odrzucono 15, a do ostatecznych badań zakwalifikowano 150 kwestionariuszy. Odrzucone 15 kwestionariuszy nie spełniało wymogów materiału badawczego (na połowę pytań nie udzielono odpowiedzi). Każdy kwestionariusz ankiety zawierał pytania ogólne dotyczące miejsca i stażu pracy, płci, wieku, wykształcenia ankietowanych i odbytych szkoleń oraz 17 pytań merytorycznych na temat znajomości problematyki RKO. Pytania dotyczyły przede wszystkim rozpoznania nagłego zatrzymania krążenia i decyzji o podjęciu resuscytacji oraz znajomości procedur BLS m.in. sposobu udrożnienia dróg oddechowych, ułożenia rąk na klatce piersiowej, częstości uciśnięć klatki piersiowej, stosunku uciśnięć do wentylacji, zastosowania automatycznego defibrylatora zewnętrznego oraz sposobu postępowania z pacjentem nieprzytomnym z zachowanym oddechem. We wspomnianych pytaniach spośród czterech odpowiedzi należało wybrać jedną poprawną. Dane przedstawiono jako odsetek lub liczbę udzielonych odpowiedzi.

\section{Wyniki}

\subsection{Znajomość zasad prowadzenia RKO w zależności od miejsca pracy}

Spośród badanych grup najwięcej prawidłowych odpowiedzi na ogół pytań udzielili ratownicy pracujący w WOPR (79\%), następnie strażacy z PSP (59\%) oraz funkcjonariusze policji (52\%). Strażacy OSP udzielili 46\% prawidłowych odpowiedzi (ryc. 1). Wszystkie ankietowane osoby deklarowały przynależność tylko do jednej z jednostek: WOPR, PSP, OSP lub policji.

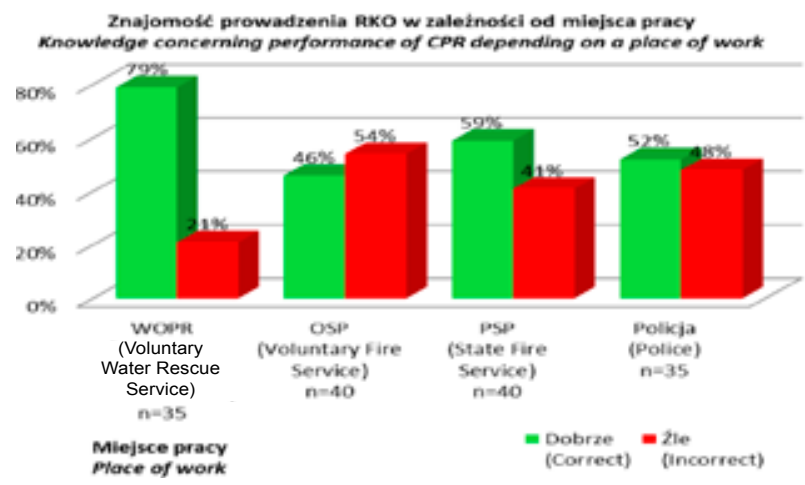

Ryc. 1. Znajomość prowadzenia RKO w zależności od miejsca pracy

Fig. 1. Knowledge concerning performance of CPR depending on a place of work

Źródło: Opracowanie własne.

Source: Own elaboration.

\subsection{Znajomość zasad wykonywania RKO w zależności od wieku badanych}

Ankietowaną populację najliczniej reprezentowały osoby do 40 . roku życia, które stanowiły $82 \%$ badanych (ryc. 2).

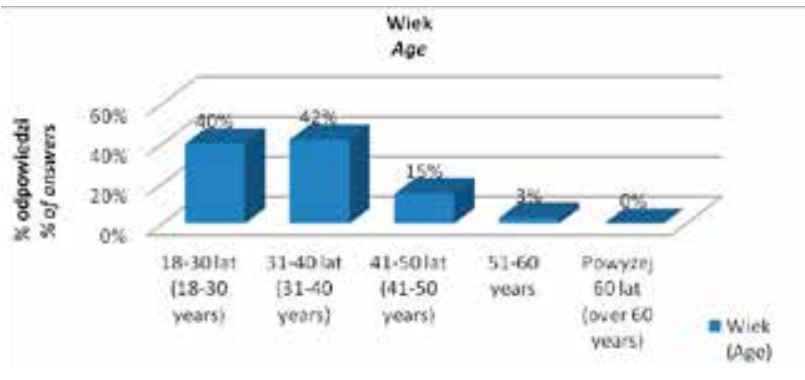

Ryc. 2. Osoby ankietowane według wieku

Fig. 2. Respondents according to their age

Źródło: Opracowanie własne. Source: Own elaboration.

Największy odsetek prawidłowych odpowiedzi na ogół pytań obserwowano w grupach wiekowych 18-30 lat oraz 31-40 lat - odpowiednio $72 \%$ i $60 \%$. Odsetek prawidłowych odpowiedzi udzielonych przez osoby powyżej 50. roku życia wyniósł jedynie 32\% (ryc. 3). 


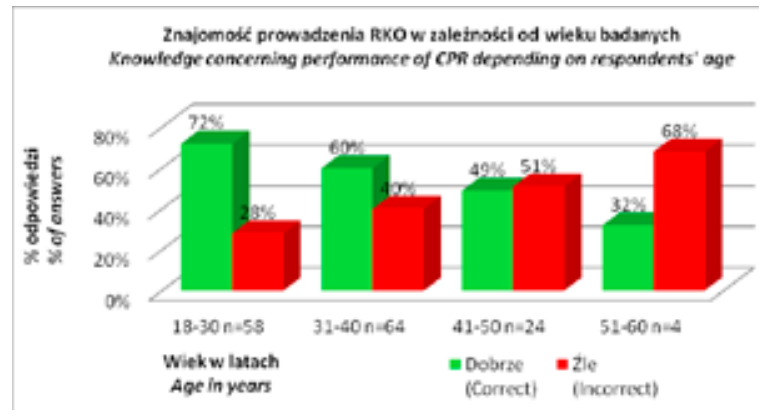

Ryc. 3. Znajomość prowadzenia RKO w zależności od wieku badanych

Fig. 3. Knowledge concerning performance of CPR depending on respondents' age Źródło: Opracowanie własne. Source: Own elaboration.

\subsection{Znajomość zasad prowadzenia RKO w zależności od wykształcenia respondentów}

We wszystkich badanych jednostkach dominowały osoby z wykształceniem średnim (58-72\%). Ponadto w przypadku policji, WOPR i PSP odnotowano odsetek ankietowanych z wykształceniem wyższym - odpowiednio $42 \%$, $34 \%$ i $28 \%$ badanych. Osoby z wykształceniem zawodowym odnotowano jedynie w OSP i stanowiły one $40 \%$ badanych, przy jednoczesnym braku osób z wykształceniem wyższym w tej grupie (ryc. 4).

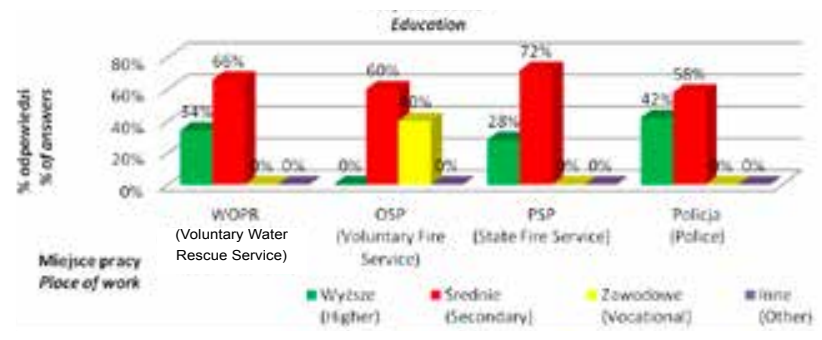

Ryc. 4. Respondenci według wykształcenia

Fig. 4. Respondents according to their education level

Źródło: Opracowanie własne. Source: Own elaboration.

Odsetek udzielonych prawidłowych odpowiedzi korelował z poziomem wykształcenia badanych (ryc. 5).

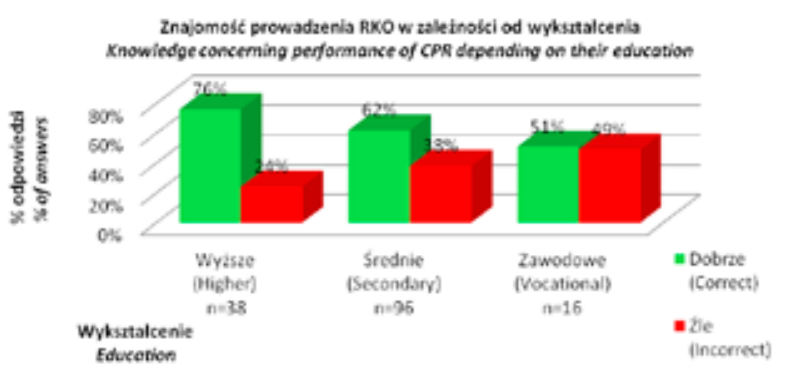

Ryc. 5. Znajomość prowadzenia RKO w zależności od wykształcenia respondentów

Fig. 5. Knowledge concerning performance of CPR depending on the education level of respondents Źródło: Opracowanie własne. Source: Own elaboration.

\subsection{Znajomość zasad prowadzenia RKO w zależności od przebytych kursów/szkoleń}

Wszyscy ankietowani strażacy PSP i OSP oraz ratownicy WOPR uczestniczyli w kursie/szkoleniu w zakresie BLS. Jedynie $17 \%$ policjantów deklarowało, że nie brali oni udziału w żadnym szkoleniu (ryc. 6).

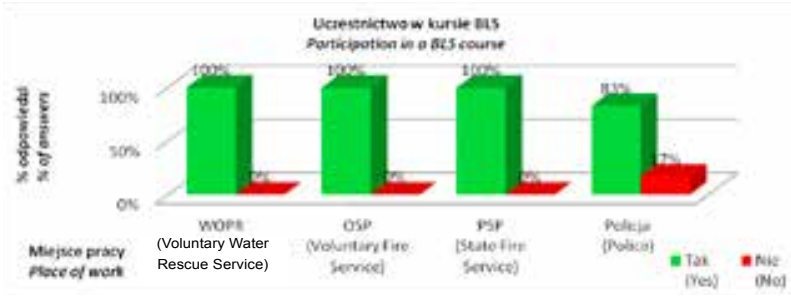

Ryc. 6. Deklaracja uczestnictwa w kursie/szkoleniu z zakresu BLS

Fig. 6. Declaration of participation in a BLS (Basic Life Support) course

Źródło: Opracowanie własne. Source: Own elaboration.

Większość badanych pracujących w WOPR, OSP i policji - odpowiednio 80\%, 68\% i 69\% - uczestniczyło tylko $\mathrm{w}$ jednym kursie/szkoleniu w ciągu ostatnich trzech lat poprzedzających badanie (ryc. 7).

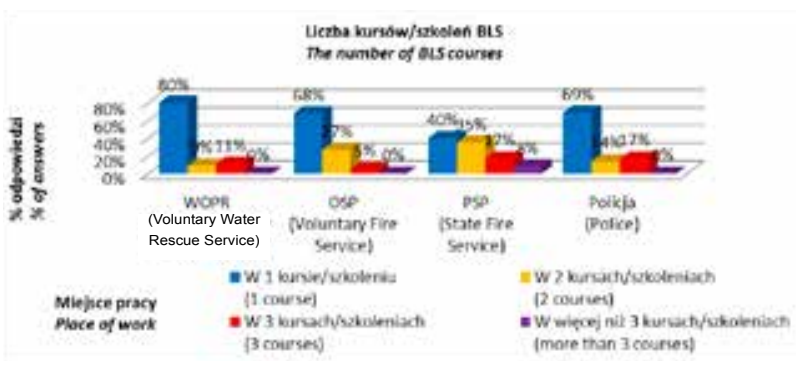

Ryc. 7. Liczba przebytych kursów/szkoleń z zakresu BLS w ciągu ostatnich trzech lat

Fig. 7. The number of BLS courses completed during the last three years

Źródło: Opracowanie własne. Source: Own elaboration.

Rycina 8 przedstawia odsetek badanych w poszczególnych grupach w zależności od czasu, który upłynął od zakończenia ostatniego szkolenia w zakresie BLS.

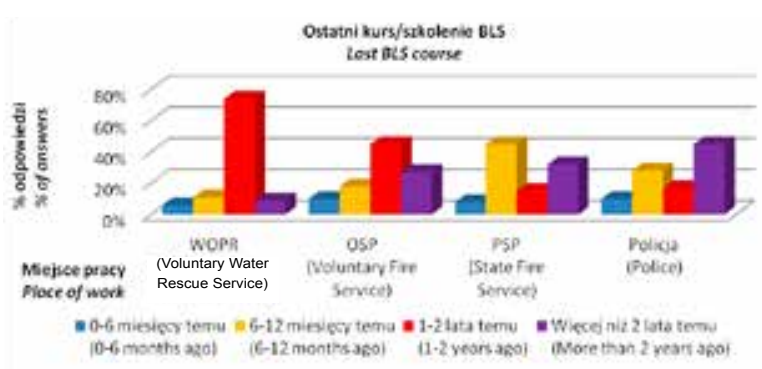

Ryc. 8. Ostatni kurs/szkolenie z zakresu BLS

Fig. 8. Last BLS course

Źródło: Opracowanie własne. Source: Own elaboration. 
Oprócz kursu/szkolenia w zakresie BLS część ankietowanych ukończyła kurs KPP i uzyskała tytuł ,ratownika. Odsetek takich osób w WOPR, PSP, policji i OSP wynosił odpowiednio $100 \%, 65 \%$, 14\% i 0\%. Powyższe dane przedstawia ryc. 9.

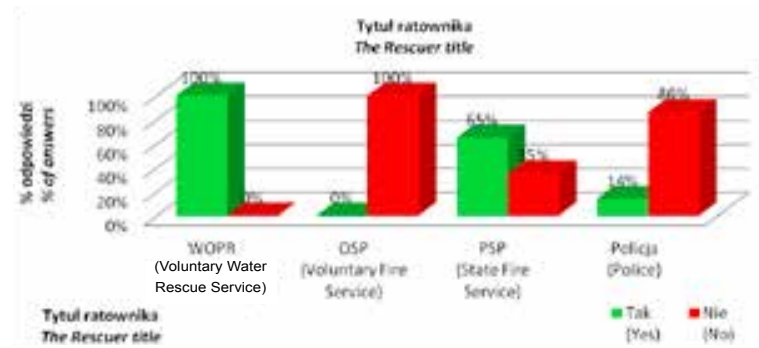

Ryc. 9. Uczestniczenie w KPP i uzyskanie tytułu ratownika przez osoby badane

Fig. 9. Participation in the course of qualified first aid and obtaining the Rescuer title

Źródło: Opracowanie własne. Source: Own elaboration.

Poziom wiedzy badanych osób mierzony odsetkiem prawidłowych odpowiedzi okazał się zbliżony niezależnie od liczby przebytych kursów/szkoleń, a odsetek prawidłowych odpowiedzi wahał się pomiędzy $58 \%$ a $62 \%$ (ryc. 10).

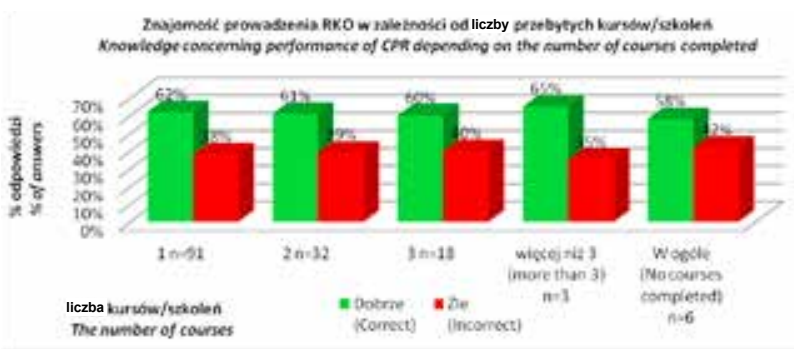

Ryc. 10. Znajomość prowadzenia RKO w zależności od liczby przebytych kursów/szkoleń

Fig. 10. Knowledge concerning performance of CPR depending on the number of courses completed

Źródło: Opracowanie własne. Source: Own elaboration.

\subsection{Znajomość zasad prowadzenia RKO w zależności od stażu pracy badanych}

Ankietowani to w przeważającej mierze osoby pracujące w systemie do 10 lat (62\% badanych). Niniejsze dane prezentuje ryc. 11 .

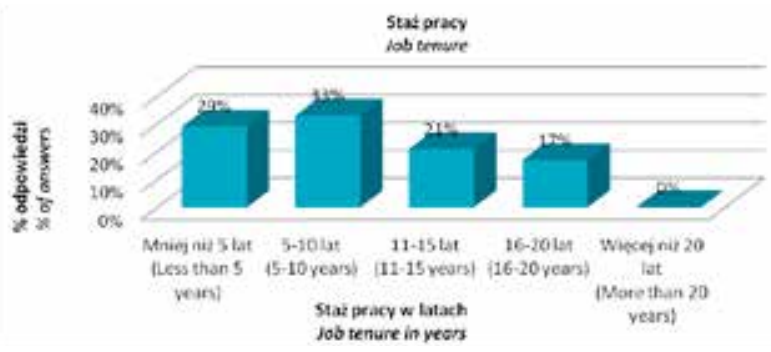

Ryc. 11. Badane osoby według stażu pracy

Fig. 11. Respondents according to job tenure Źródło: Opracowanie własne. Source: Own elaboration.
Najwięcej prawidłowych odpowiedzi uzyskali respondenci z krótkim stażem pracy, tzn. ci, którzy pracują mniej niż 5 lat (76\%), a następnie ci, którzy pracują 5-10 lat (64\%). Najsłabiej odpowiadały na zadawane pytania osoby $z$ dłuższym stażem pracy. Powyższe wyniki badań prezentowane są na ryc. 12 .

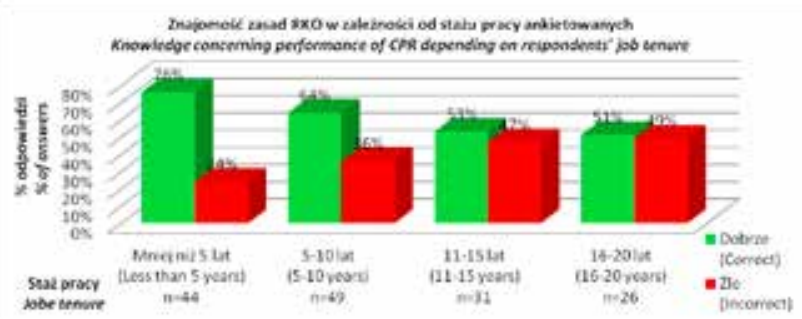

Ryc. 12. Znajomość prowadzenia RKO w zależności od stażu pracy ankietowanych

Fig. 12. Knowledge concerning performance of CPR depending on respondents' job tenure Źródło: Opracowanie własne. Source: Own elaboration.

\subsection{Ogólna znajomość zasad prowadzenia RKO przez badane osoby}

Ogółem na 17 pytań dotyczących wiedzy uzyskano 61\% prawidłowych odpowiedzi, biorąc pod uwagę wszystkie badane grupy (ryc. 13)

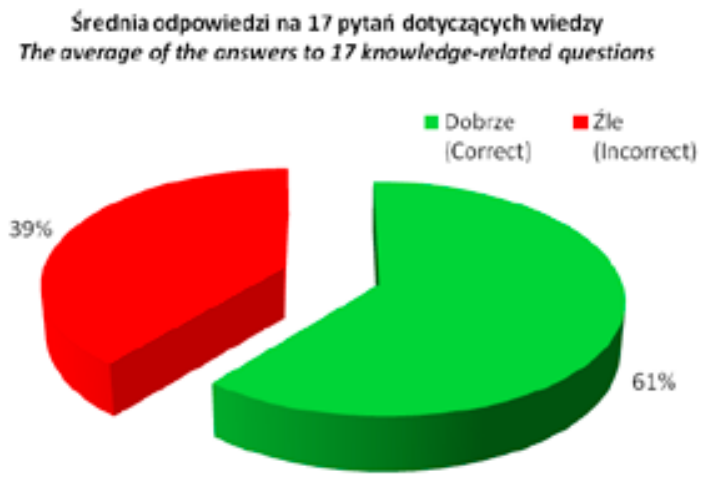

Ryc. 13. Średnia odpowiedzi badanych na pytania dotyczące wiedzy o RKO

Fig. 13. The average of the respondents' answers to the questions with regard to knowledge concerning CPR

Źródło: Opracowanie własne. Source: Own elaboration.

\subsection{Analiza wybranych pytań ankietowych}

\section{Kiedy rozpoczynamy resuscytację krążeniowo-oddechową?}

Osoby pracujące w WOPR i PSP w ponad $80 \%$ przypadków potrafiłyby prawidłowo rozpoznać zatrzymanie krążenia (odpowiedź w ankiecie - „pacjent nieprzytomny, bez oznak krążenia”) i podjąć decyzję o resuscytacji. Przeciwnie policjanci oraz strażacy OSP - ci rozpoznaliby zatrzymanie krążenia i, co za tym idzie, wdrożyli prawidłowo RKO w ok. 50\% przypadków. Pozostali rozpoczęliby RKO w sytuacji, kiedy poszkodowany jest przytomny, ale 
w ciężkim stanie lub gdy nastąpiła nagła utrata przytomności z drgawkami - takie odpowiedzi zostały wybrane w ankiecie. Odsetek udzielonych prawidłowych/błędnych odpowiedzi pokazuje ryc. 14 .

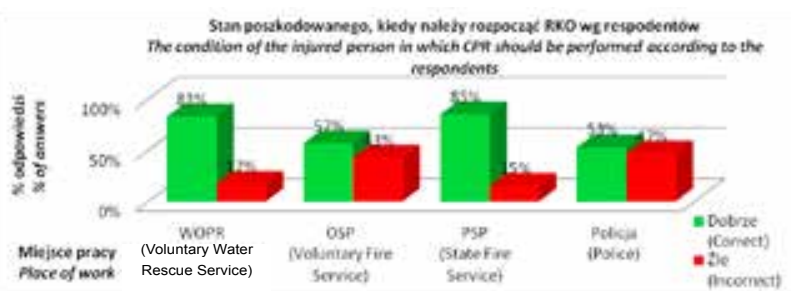

Ryc. 14. Stan poszkodowanego wskazujący na rozpoczęcie RKO wg respondentów

Fig. 14. The condition of the injured person in which CPR should be performed according to the respondents

Źródło: Opracowanie własne.

Source: Own elaboration.

\section{W jaki sposób należy prawidłowo udrożnić drogi oddechowe?}

Ważnym elementem BLS jest udrożnienie dróg oddechowych poprzez odchylenie głowy do tyłu i uniesienie żuchwy. Tę prawidłową czynność wskazywali strażacy PSP (92\%), następnie ratownicy WOPR $(80 \%)$, policjanci (71\%) i strażacy OSP (57\%). Respondenci, którzy udzielili niepoprawnej odpowiedzi, udrożniliby drogi oddechowe jedynie poprzez otwarcie ust poszkodowanego, odwrócenie głowy na bok lub ułożenie w pozycji bezpiecznej z głową skierowaną ku klatce piersiowej. Odsetek udzielonych prawidłowych/błędnych odpowiedzi pokazuje ryc. 15 .

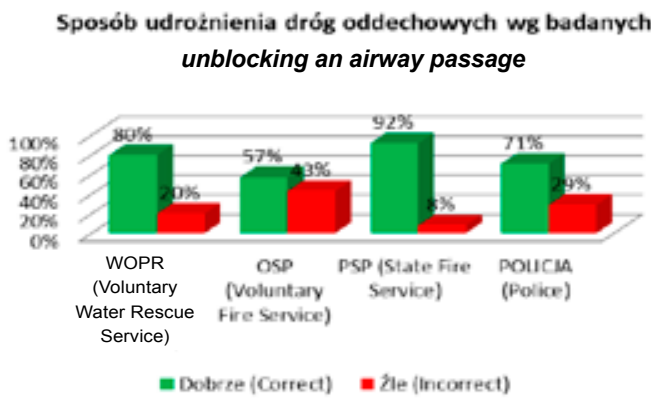

Ryc. 15. Sposób udrożnienia dróg oddechowych wg badanych

Fig. 15. The way of unblocking an airway passage according to the respondents

Źródło: Opracowanie własne. Source: Own elaboration.

\section{W którym miejscu klatki piersiowej ułoży Pan/ Pani dłonie celem uciskania klatki piersiowej podczas RKO u osoby dorosłej?}

Prawidłową odpowiedź - „na środku klatki piersiowej” wybrało 74\% ankietowanych z WOPR, 50\% z PSP, 27\% z OSP i tylko $20 \%$ z policji. Pozostałe osoby niepoprawnie określiły wybór miejsca ucisku klatki piersiowej, podając, że ułożyłyby ręce po lewej stronie klatki piersiowej lub na wysokości 1/3 dolnej części mostka albo 2 palce poniżej mostka. Wyniki zestawiono na ryc. 16.

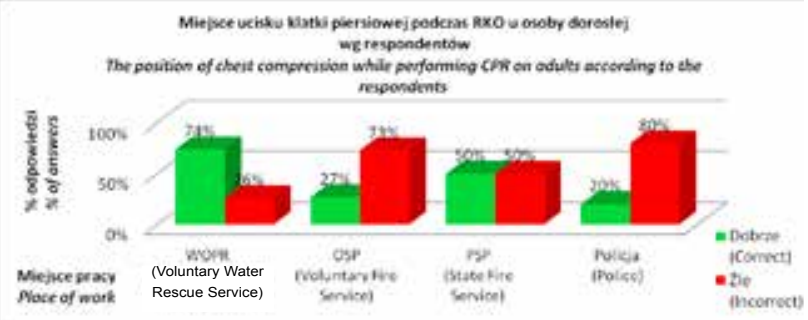

Ryc. 16. Deklaracje osób współpracujących z systemem o znajomości miejsca ucisku klatki piersiowej podczas RKO u osoby dorosłej

Fig. 16. Respondents' declarations as regards the knowledge concerning the position of chest compression when performing CPR on adults Źródło: Opracowanie własne. Source: Own elaboration.

\section{Jaka jest prawidłowa częstość uciśnięć klatki piersiowej podczas RKO?}

Odpowiedź prawidłową, czyli 100-120/minutę, wybrało $80 \%$ ankietowanych pracujących w WOPR, 55\% badanych z PSP, 33\% z OSP i tylko $17 \%$ ankietowanych z policji. Badani, którzy wybrali nieprawidłowe odpowiedzi, uważali, że klatkę piersiową należy uciskać z częstością 60 lub 90 razy na minutę. Nikt nie udzielił odpowiedzi, że powyżej 120 razy na minutę. Wyniki przedstawia ryc. 17.

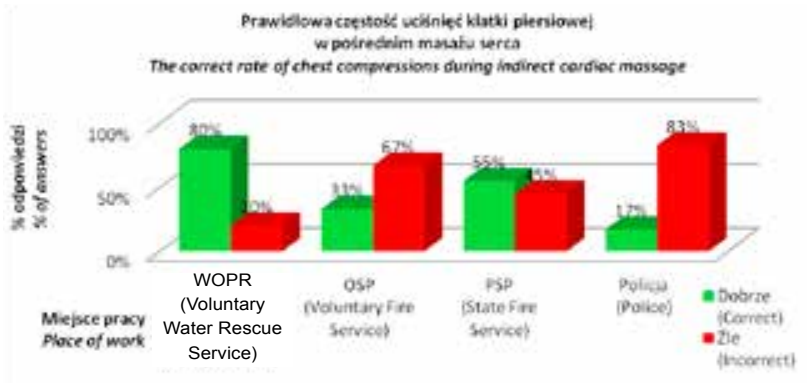

Ryc. 17. Częstość uciśnięć klatki piersiowej w pośrednim masażu serca wg badanych

Fig. 17. The rate of chest compressions during indirect cardiac massage according to the respondents Źródło: Opracowanie własne. Source: Own elaboration.

\section{Jaki jest prawidłowy stosunek liczby uciśnięć klatki piersiowej u osób dorosłych do liczby oddechów ratowniczych?}

Większość respondentów prowadziłaby uciskanie klatki piersiowej i oddechy ratownicze $\mathrm{z}$ prawidłową częstością (WOPR - 86\%, PSP - 70\%, OSP - 65\%, policja - 60\%). Dla pozostałych badanych prawidłową częstością było w większości 15:2. Wyniki obrazuje ryc. 18. 
Prawidłowy stosunek liczby uciśnięć klatki piersiowej do liczby oddechów ratowniczych wg ankietowanych The correct compression-ventilation ratio according the responders

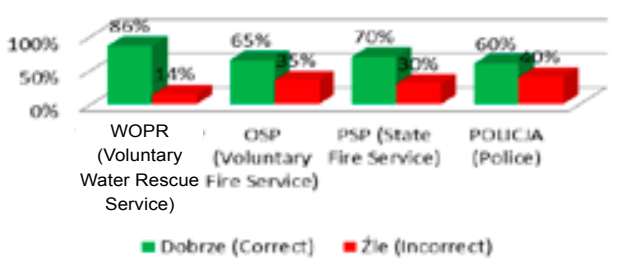

Ryc. 18. Stosunek liczby uciśnięć klatki piersiowej do liczby oddechów ratowniczych wykonywanych podczas BLS osoby dorosłej wg badanych

Fig. 18. The correct compression-ventilation ratio according to the respondents Źródło: Opracowanie własne. Source: Own elaboration.

\section{Co to jest defibrylacja automatycznym defibrylatorem zewnętrznym?}

Większość badanych (WOPR - 89\%, OSP - 73\%, PSP - 68\%, policja - 57\%) udzieliło prawidłowej odpowiedzi, że jest to zabieg polegający na zastosowaniu impulsu elektrycznego w celu przywrócenia prawidłowej pracy serca. Wyniki przedstawiono na ryc. 19.

\section{Znajomość pojęcia defibrylacji automatycznej wg respondentów \\ Knowledge about automatic external defibrillation according to the respondents}

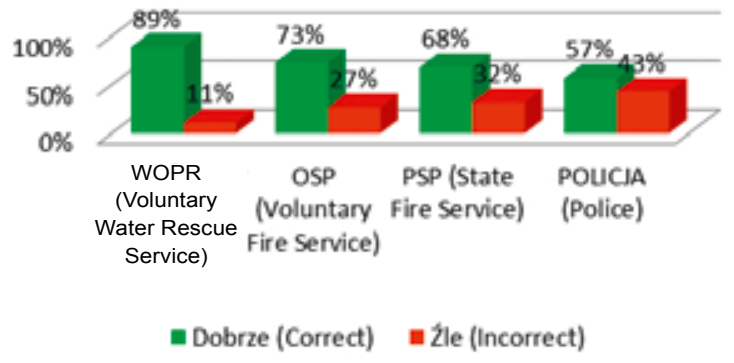

Ryc. 19. Znajomość pojęcia defibrylacji automatycznej wg badanych

Fig. 19. Knowledge about automatic external defibrillation according to the respondents

Źródło: Opracowanie własne. Source: Own elaboration.

\section{Jak ułożyć poszkodowanego nieprzytomnego $\mathrm{z}$ zachowanym oddechem?}

Poszkodowanego nieprzytomnego z zachowanym oddechem należy ułożyć w pozycji bezpiecznej, czyli na boku z głową odgiętą ku tyłowi (prawidłowa odpowiedź w ankiecie). Prawidłowej odpowiedzi udzielili wszyscy ratownicy pracujący w WOPR, 65\% strażaków z OSP, 60\% funkcjonariuszy policji i jedynie 35\% strażaków PSP. Ankietowani, którzy udzielili złej odpowiedzi, ułożyliby osobę nieprzytomną z zachowanym oddechem na plecach z kończynami do góry lub na plecach, a pod głowę podłożyliby zwiniętą tkaninę.
Niewielki odsetek badanych deklaruje ułożenie na brzuchu z głową skierowaną w bok. Dane obrazuje ryc. 20.

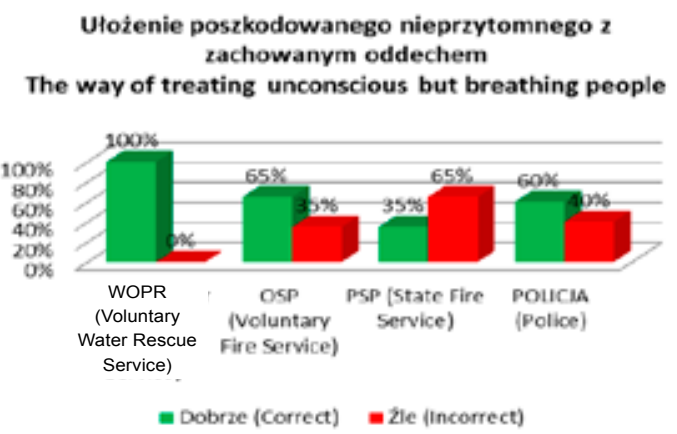

Ryc. 20. Ułożenie poszkodowanego nieprzytomnego z zachowanym oddechem

Fig. 20. The way of treating unconscious but breathing people

Źródło: Opracowanie własne. Source: Own elaboration.

\section{Dyskusja}

Wprawdzie ratownicy WOPR, spośród wszystkich badanych grup, udzielili najwięcej prawidłowych odpowiedzi na ogół pytań dotyczących RKO, ale wynik 79\% trudno uznać za satysfakcjonujący. Jeżeli przyjrzeć się odpowiedziom na wybrane pytania, okazuje się, że spośród 35 ankietowanych ratowników WOPR sześciu nie potrafiłoby prawidłowo rozpoznać zatrzymania krążenia, siedmiu uciskałoby klatkę piersiową z nieprawidłową częstością, a dziewięciu nieprawidłowo ułożyłoby ręce na klatce piersiowej podczas jej uciskania. Powyższe dane są tym bardziej trudne do zaakceptowania, że wszyscy ankietowani ratownicy WOPR deklarowali ukończenie kursu KPP, pozytywne złożenie egzaminu państwowego i posiadanie ważnego zaświadczenia o nadaniu tytułu ratownika w rozumieniu rozporządzenia Ministra Zdrowia [3]. Wykonywanie w sposób prawidłowy wysokiej jakości uciśnięć klatki piersiowej podczas RKO stanowi fundamentalną podstawę działań ratunkowych, eksponowaną w sposób szczególny w aktualnych wytycznych Europejskiej Rady Resuscytacji (ERC) [4].

W przypadku strażaków PSP i funkcjonariuszy policji odsetek prawidłowych odpowiedzi na ogół pytań wyniósł niewiele ponad połowę (odpowiednio 59\% i 52\%), a strażacy z OSP udzielili ich jedynie $46 \%$. Niemal połowa strażaków z PSP nie zna prawidłowego miejsca ani prawidłowej częstości uciśnięć klatki piersiowej podczas RKO. Niemal co drugi strażak z OSP i co drugi policjant nie rozpoznałby prawidłowo zatrzymania krążenia, a jedynie jeden na czterech badanych strażaków OSP i jeden na pięciu ankietowanych policjantów potrafił prawidłowo określić miejsce ucisku klatki piersiowej. Tylko $17 \%$ policjantów podało prawidłowo częstość uciśnięć klatki piersiowej, co pomimo upływu przeszło pięciu lat stanowi wynik podobny do osiągniętego w badaniu przeprowadzonym wśród pracowników Ośrodka Ratownictwa Medycznego w 2007 roku przez Mroczkowską i wsp. - adekwatnie 18\% [5]. Badanie ankietowe przeprowadzone przez Dąbrowskiego i wsp. wskazuje również na potrzebę uzupełnienia wiedzy 
w zakresie znajomości BLS u strażaków PSP, zwłaszcza w zakresie sekwencji działań w trakcie resuscytacji krążeniowo-oddechowej, gdzie odsetek prawidłowych odpowiedzi wynosił jedynie $14 \%$ [6].

Spośród ratowników WOPR oraz strażaków PSP i OSP - wszyscy ankietowani deklarowali udział w szkoleniach w zakresie BLS organizowanych przez pracodawców. Podobną deklarację złożyło 83\% policjantów. Większość respondentów z wszystkich grup uczestniczyła w jednym szkoleniu w okresie ostatnich dwóch lat, jedynie w policji $45 \%$ osób deklarowało udział w szkoleniu w zakresie BLS ponad 2 lata temu, co w połączeniu $\mathrm{z}$ faktem braku jakiegokolwiek szkolenia BLS deklarowanym przez $17 \%$ ankietowanych policjantów, mogło mieć wpływ na prezentowany poziom wiedzy w tej grupie.

Według zaleceń ERC szkolenia w zakresie procedur BLS powinny odbywać się cyklicznie, a powtarzalność szkoleń ma warunkować należyte utrwalenie wiedzy i umiejętności. W naszych badaniach okazało się, że liczba przebytych szkoleń nie miała istotnego wpływu na odsetek udzielonych prawidłowych odpowiedzi przez ogół ankietowanych (ryc. 4e). Zatem pozostaje pytanie o jakość prowadzonych kursów, zaangażowanie słuchaczy w nich uczestniczących oraz formę sprawdzenia wiadomości.

Na podstawie przeprowadzonych badań można stwierdzić, że w grupie osób, które wykazały się najlepszym poziomem wiedzy na temat $\mathrm{RKO}$, przeważały osoby młodsze (18-40 lat), z wyższym (76\%) lub średnim (62\%) wykształceniem oraz te osoby, które krótko pracują w swoim zawodzie (mniej niż 5 lat - 76\% prawidłowych odpowiedzi). Odsetek prawidłowych odpowiedzi łącznie we wszystkich badanych grupach wprawdzie korelował z młodszym wiekiem, krótszym stażem pracy i poziomem wykształcenia ankietowanych, ale wydaje się, że na wynik badania wpływa jednocześnie wiele zmiennych, które należy oceniać łącznie. Sam na przykład poziom wykształcenia nie daje podstaw do jednoznacznych oczekiwań osiągnięcia lepszych wyników ankiety - w grupie policjantów obserwowano najwyższy odsetek osób z wykształceniem wyższym (42\%), a udzielono 52\% prawidłowych odpowiedzi, podczas gdy w PSP odsetek ten wynosił $28 \%$ przy $59 \%$ odpowiedziach prawidłowych.

Wyniki pracy odnoszą się w całości do wiedzy teoretycznej ankietowanych. Pomimo odbytych szkoleń zarówno w zakresie podstawowych zabiegów ratujących życie, jak i kwalifikowanej pierwszej pomocy, ankietowani nie wykazali się należytą wiedzą we wspomnianym zakresie. Rodzi się zatem pytanie o przyczynę takiej sytuacji oraz możliwości jej poprawy. Przyczyny upatrywać należy prawdopodobnie w nieefektywnym systemie kształcenia osób współpracujących z systemem PRM. Należałoby przyjrzeć się programom szkoleń BLS zarówno w zakresie zawartości materiału dydaktycznego, formy przekazu informacji, jak i liczby godzin zajęć. Szkolenia BLS oferowane są przez różne podmioty świadczące działalność edukacyjną i nie podlegają ujednoliconym standardom kształcenia. Nie ma tu również ujednoliconych wymogów co do sprawdzenia wiedzy nabytej na kursie, najlepiej przez komisję spoza podmiotu szkolącego, co byłoby miernikiem efektywności danego kursu. Zatem ocena słuchaczy i wydanie certyfikatu ukończenia kursu zależy wyłącznie od podmiotu szkolącego. Pamiętać należy również o konieczności ustawicznego powtarzania i utrwalania nabytej na kursach wiedzy i umiejętności, w przypadku BLS nie rzadziej niż co 6 miesięcy, jak zalecają wytyczne ERC [2]. W przypadku kursu kwalifikowanej pierwszej pomocy program kształcenia jest ściśle określony zgodnie ze stosownym rozporządzeniem Ministra Zdrowia [3], ale pomimo tego osiągany efekt w postaci wiedzy okazał się niezadowalający. Być może należałoby przeprowadzić szczegółową ankietę pośród osób, które odbyły kurs KPP, co pozwoliłoby na podstawie spostrzeżeń reprezentatywnej grupy słuchaczy znaleźć przyczynę tej sytuacji. Niewątpliwie uzyskane wyniki wskazujące na niedobór wiedzy teoretycznej powinny być zestawione $\mathrm{z}$ oceną umiejętności praktycznych udzielania pierwszej pomocy zarówno w zakresie podstawowym, jak i kwalifikowanym.

\section{Podsumowanie i wnioski}

Poziom wiedzy badanych osób zatrudnionych w jednostkach współpracujących z systemem PRM jest niewystarczający. Ankietowani udzielili $61 \%$ prawidłowych odpowiedzi na zadane pytania. System szkoleń, w których uczestniczyli ankietowani ratownicy WOPR, strażacy PSP i OSP oraz policjanci, należy uznać za mało efektywny w zakresie wiedzy teoretycznej dotyczącej RKO. Uzyskane wyniki stanowią inspirację dla autorów pracy do podjęcia badań dotyczących umiejętności praktycznych osób współpracujących z systemem PRM w zakresie udzielania pierwszej pomocy.

\section{Wykaz skrótów}

ALS - zaawansowane zabiegi ratujące życie
BLS - podstawowe zabiegi ratujące życie
ERC - Europejska Rada Resuscytacji
KPP - kwalifikowana pierwsza pomoc
OSP - Ochotnicza Straż Pożarna
PRM - Państwowe Ratownictwo Medyczne
PSP - Państwowa Straż Pożarna
RKO - resuscytacja krążeniowo-oddechowa
WOPR - Wodne Ochotnicze Pogotowie Ratunkowe 


\section{Literatura}

[1] Wiszniewska M., Kobayashi A., Członkowska A., Postępowanie w udarze mózgu. Skrót Wytycznych Grupy Ekspertów Sekcji Chorób Naczyniowych Polskiego Towarzystwa Neurologicznego z 2012 roku, „Polski Przegląd Neurologiczny", Vol. 8 Issue 4, 2012, pp. 161-175.

[2] Koster R. W., Baubin M. A., Caballero A., i in., European Resuscitation Council Guidelines for Resuscitation 2010. Section 2. Adult basic life support and use of automated external defibrillators, "Resuscitation", Vol. 81 Issue 10, 2010, pp. 1277-92.

[3] Rozporządzenie Ministra Zdrowia z dnia 19 marca $2007 \mathrm{r}$. w sprawie kursu w zakresie kwalifikowanej pierwszej pomocy (Dz.U. 2007 Nr 60, poz. 408).
[4] Nolan J.P., Soar J., Zideman D.A., i in., European Resuscitation Council Guidelines for Resuscitation 2010, Section 1, Executive Summary, "Resuscitation", Vol. 81 Issue 10, 2010, pp. 1219-1276.

[5] Mroczkowska M., Gaszyński W., Poziom znajomości wytycznych resuscytacji krążeniowo-oddechowej wśród pracowników Ośrodka Ratownictwa Medycznego w Skierniewicach, „Med. Intens. Ratun”, Vol. 10 Issue 1, 2007, pp. 7-11.

[6] Dąbrowski M., Dąbrowska A., Sip M., i in., Badanie wiedzy $w$ zakresie podstawowych zagadnień resuscytacji u ratowników PSP, studentów medycyny i lekarzy stażystów, „Nowiny Lekarskie”, Vol. 81 Issue 6, 2012, pp. 647-652.

dr n. med. Sławomir Pilip - specjalista neurolog, specjalista medycyny ratunkowej. Od 2006 roku adiunkt w Zakładzie Ratownictwa Medycznego Warszawskiego Uniwersytetu Medycznego. Z-ca Dyrektora ds. Lecznictwa RM Meditrans Stacji Pogotowia Ratunkowego i Transportu Sanitarnego w Siedlcach. Członek Polskiego Towarzystwa Medycyny Ratunkowej.

mgr Anita Wójcik - ukończyła studia magisterskie na kierunku pielęgniarstwo w Warszawskim Uniwersytecie Medycznym. Ukończyła kurs specjalistyczny i kwalifikacyjny w dziedzinie anestezjologii. Pracuje na Oddziale Intensywnej Opieki Kardiologicznej w Wojewódzkim Szpitalu Chirurgii Urazowej w Warszawie.

dr n. med. Grzegorz Michalak - specjalista chirurgii ogólnej, transplantologii klinicznej i medycyny ratunkowej. Od 2006 roku kierownik Zakładu Ratownictwa Medycznego Wydziału Nauki o Zdrowiu Warszawskiego Uniwersytetu Medycznego. Od 2003 roku Ordynator Szpitalnego Oddziału Ratunkowego w Szpitalu Bielańskim w Warszawie. W 2001 roku ukończył podyplomowe studia menedżerskie na Wydziale Zarządzania Uniwersytetu Warszawskiego. Od 2007 roku Zastępca Dyrektora ds. Lecznictwa w Szpitalu Bielańskim w Warszawie. Od 2011 roku konsultant wojewódzki na Mazowszu w dziedzinie medycyny ratunkowej.

dr n. med. Robert Gałązkowski - adiunkt w Zakładzie Ratownictwa Medycznego Warszawskiego Uniwersytetu Medycznego, dyrektor SP ZOZ Lotnicze Pogotowie Ratunkowe. W 2005 uzyskał stopień doktora nauk medycznych na Wydziale Nauk o Zdrowiu Uniwersytetu Medycznego w Łodzi. W 2006 w Kolegium Zarządzania i Finansów w Szkole Głównej Handlowej w Warszawie ukończył podyplomowe studia w zakresie zarządzania organizacjami ochrony zdrowia. W 2014 roku ukończył podyplomowe studia „Zarządzanie podmiotami leczniczymi przekształcanymi w spółki prawa handlowego”. Członek Polskiego Towarzystwa Medycyny Ratunkowej, Stowarzyszenia na Rzecz Leczenia Ciężkich Krwotoków, członek zarządu Europejskiego Komitetu HEMS i Pogotowia Lotniczego (EHAC). Inicjator powstania i redaktor naczelny czasopisma naukowego „Emergency Medical Service - Ratownictwo Medyczne”. 